\title{
A Retrospective Study on Urinary Tract Infection Agents Isolated from Children and Their Antibiotic Susceptibility
}

\section{Çocuklardan İzole Edilen İdrar Yolu Enfeksiyonu Etkenlerinin ve Antibiyotik Duyarlılıklarının Retrospektif Değerlendirilmesi}

\author{
Neslihan Idil ${ }^{1 *}$, Esra Deniz Candan ${ }^{2}$, Abbas Yousefi Rad $^{3 \odot}$ \\ ${ }^{1}$ Department of Biology, Faculty of Sciences, Hacettepe University, Ankara, Turkey. \\ ${ }^{2}$ Vocational School of Health Services, Giresun University, Giresun, Turkey. \\ ${ }^{3}$ Clinical Microbiology, Koru Hospitals, Yüksek intisas University, Ankara, Turkey.
}

\section{ABSTRACT}

\begin{abstract}
$\Lambda$ ntibiotics are important agents in the treatment of urinary tract infection (UTI). However, the use of antibiotics is an important risk factor causing antibiotic resistance. Antibiotic inappropriate resistance is one of the most important problems of increased uropathogenic resistance, especially in pediatric urology. Deficiencies in empirical prescription practices can make this problem even worse. In this study, the demographic characteristics of pediatric patients, UTI agents, and antibiotic resistance of these agents were retrospectively evaluated by an automated system. The data from 719 UTI agents isolated from children were separately analyzed for four different age groups (0-2, 2-6, 6-12, and 12-17). The most commonly isolated infection agents were Escherichia coli (68.01\%), Klebsiella pneumoniae (19.75\%), Klebsiella oxytoca (3.34\%), Enterobacter cloacae (2.23\%), and Pseudomonas aeruginosa (1.95\%). Among the age groups, 0 -2 age group was quite diverse in terms of infection agents and antibiotic resistance values of these agents were significantly high in this group ( $p<0.05)$. Regarding the antibiotic resistance, the most noteworthy ones were the resistance against ampicillin (70.2\%), amoxicillinclavulanate (49.0\%), cefixime (38.2\%), and trimethoprim/sulfamethoxazole (37.1\%). Our study indicated that children in $0-2$ age group were under higher risk in terms of UTI agents and their antibiotic resistance but this risk was reduced with increasing age. Moreover, the ratio of girls with UTI was greater than that of boys within 0-2 age group. There was high resistance against cephalosporin, ampicillin, amoxicillin-clavulanate, and trimethoprim/sulfamethoxazole, whereas the resistance against carbapenem (imipenem, ertapenem and meropenem) was found to be low and there was no significant increase.
\end{abstract}

Key Words

Antibiotic resistance, Escherichia coli, pediatric urology, urinary tract infection.

\section{öz}

\begin{abstract}
ntibiyotikler idrar yolu enfeksiyonlarının tedavisinde önemli bir dayanak noktası olmasına rağmen, bilinçsiz kullanımlar Aantibiyotik direncinin gelişimi için önemli bir risk faktörüdür. Antibiyotik direnci, özellikle çocuk ürolojisinde, artan üropatojen direncinin en önemli sorunlarından bir olarak karşımıza çıkmaktadır. Ampirik reçete uygulamalarındaki eksiklikler bu sorunu daha da kötüleştirmektedir. Bu çalışmada; pediatrik hastaların demografik özellikleri, idrar yolu enfeksiyonu etkenleri ve bu etkenlerin antibiyotik direnç durumları otomatize sistem ile retrospektif olarak değerlendirilmiştir. Çocuklardan izole edilen 719 idrar yolu enfeksiyonu etkeninden elde edilen veriler dört pediatrik yaş grubu (0-2 yaş, 2-6 yaş, 6-12 yaş ve 12-17 yas) için ayrı ayrı analiz edildi. En sık izole edilen enfeksiyon etkenleri sırasıyla; Escherichia coli (\%68.01), Klebsiella pneumoniae (\%19.75), Klebsiella oxytoca (\%3.34), Enterobacter cloacae (\%2.23) ve Pseudomonas aeruginosa (\%1,95) şeklindedir. Yaş grupları içerisinde; 0-2 yaş grubu enfeksiyon etkenleri açısından oldukça çeşitlilik göstermektedir. Aynı zamanda; bu grup içerisinde bu etkenlerin sahip olduğu antibiyotik dirençlerinin anlamlı bir şekilde yüksek olduğu saptanmıştır $(p<0.05)$. Antibiyotik direnç durumları incelendiğinde; en dikkat çekici olanlar ampisilin (\%70.2), amoksisilin-kluvanat (\%49.0), cefixime (\%38.2) ve trimetoprim/sülfametoksazol (\%37.1)'e olan dirençlerdir. Çalışmamızda, 0-2 yaş grubu çocukların idrar yolu enfeksiyonu etkenleri ve bu etkenlerin sahip olduğu antibiyotik direnç açısından daha fazla risk altında oldukları, yaşın artışı ile bu riskin azaldığı ve grup içerisinde idrar yolu enfeksiyonu olan kız çocuklarının oranının daha fazla olması önemli bulunmuştur. Çalışmamızda; sefalosporinlere, ampisilin, amoksisilin-klavulanat ve trimetoprim/sülfametoksazol'e karşı yüksek direnç bulunurken karbapenem (imipenem, ertapenem, meropenem) direnci düşük düzeyde saptanmış olup anlamlı olabilecek bir artış olmadığı görülmüştür.
\end{abstract}

\section{Anahtar Kelimeler}

Antibiotik direnci, Escherichia coli, pediatrik üroloji, idrar yolu enfeksiyonu. 


\section{INTRODUCTION}

$\bigcup$ rinary tract infection (UTI) is the infection of the kidneys, ureters, bladder, and urethra [1]. UTI is the second most common infection in childhood after respiratory tract infections $[2,3]$. UTI, one of the main bacterial infections causing acute morbidity, affects up to 180.000 children in the age of 6 (3-7\% girls and 1-2\% boys) according to a cumulative incidence of studies in the USA. In addition $12-30 \%$ of these children were also infected with recurrent fever infections [3]. Flora alterations, urinary tract anomalies, and immature immune system are among the causes of frequent infections in this age group $[3,4]$. Renal damage induced by recurrent fever infection causes long-term complications including hypertension, renal dysfunction and chronic renal failure in later period $[5,6]$.Thus, detection of risk factors, development of appropriate diagnostic methods, and therefore a rapid and reliable treatment of UTI are of great importance to reduce the morbidity rate and related complications. The epidemiology of UTI varies depending on age and gender. Approximately $5 \%$ of girls and $2 \%$ of boys are infected with an UTI at least once [7]. The global prevalence in children under two is 7\% [8]. In Infants, it is very difficult to identify the UTI symptoms. Clinicans should diagnose early to initiate appropriate treatment and prevent complications including hypertension and chronic kidney disease [9]. UTI frequently occurs in the adolescence period following the toilet training period after the infancy period [10]. Approximately, $60-90 \%$ of UTIs appear as pyelonephritis in the pre-school period. There is a risk of severe problems in patients who are not regularly treated or monitored for these infections $[5,8]$.

Majority of UTI agents are Escherichia coli, Klebsiella species, and Proteus species, although these agents differ depending on age and gender as well as the catheterization and hospitalization. Moreover, Enterococcus faecalis and Pseudomonas species showing high antibiotic resistance are also found in patients who were hospitalized or have anatomic anomalies [11]. Antibiotic resistance of these microorganisms varies depending on their location. In recent years, antibiotic resistance has been an increasingly important problem worldwide in the first stage of treatment [12]. Antibiotics used for the treatment include trimethoprim/sulfamethoxazole (TMP/SMX), cephalosporins, and amoxicillin [13]. Regarding the childhood UTI, E. coli, which is a common infection agent, indicates increasing resistance against beta- lactam antibiotics and TMP/SMX. Widespread antibiotic use increases the antibiotic resistance and therefore, triggers the invention of new antibiotics to be used in the treatment of infections. This situation increases the economic burden in the healthcare sector and leads to an additional increase in antibiotic resistance.

Studies on the local epidemiology of common uropathogens and their antimicrobial resistance in UTI increase the treatment success and encourage a more efficient antibiotic use. Correspondingly, this study aims to retrospectively assess the demographic characteristics, infection agents, and antibiotic resistance in pediatric patients diagnosed between 2016 and 2018.

\section{MATERIALS and METHODS}

\section{Demographic characteristics}

719 UTI agent samples were included isolated from children in a private research hospital in Ankara, Turkey between January 2016 and September 2018. The isolated samples were classified according to their age, sex, microorganisms and antibiotic susceptibility. Patients were divided into different age groups which are $0-2$, 2-6, 6-12 and 12-17.

\section{Antimicrobial resistance}

In this study, resistances of 719 UTI agent samples against 19 different antimicrobial agents were examined. These antimicrobial agents were, namely, ertapenem, imipenem, meropenem, amikacin, gentamicin, ampicillin, amoxicillin/clavulanate, piperacillin/tazobactam, ciprofloxacin, norfloxacin, cefixime, ceftazidime, ceftriaxone, cefepime, nitrofurantoin, TMP/SMX, fosfomycin, colistin, and aztreonam.

Identification of the microorganisms and determination of resistance against antimicrobial agents were carried out using an automated identification and susceptibility testing system (BD Phoenix TM, BD diagnostic systems Sparks, MD, USA). The obtained results from antimicrobial resistance testing were evaluated according to the European Committee on Antimicrobial Susceptibility Testing (EUCAST) criteria (EUCAST, version 1.3, 2011.) Infection agents and their resistance states were retrospectively evaluated.

\section{Statistical Analysis}

Data analysis was carried out using SPSS software (version 18.0, SPSS Inc. Chicago, IL). Descriptive values were 
specified as number (n), percentage (\%), and median. The normal distribution of variables was evaluated using visual (histogram and probability graphs) and analytical methods (Kolmogorov-Smirnov/Shapiro-Wilk tests). Pearson Chi-square test was used to compare the categorical variables. Continuous variables were compared using the Mann-Whitney $U$ test because they did not match the normal distribution. Homogeneity of the groups was evaluated by the Levene's test and Tamhane's posthoc test. In this study, p values below 0.05 were considered as statistically significant.

\section{RESULTS and DISCUSSION}

\section{Clinical results}

A total of 719 UTI agent samples obtained from children in the age groups of 0-2 ( $n=428), 2-6(n=153), 6-12$ ( $n=$ $116)$, and $12-17(n=22)$ were examined. In total, 16 different UTI agents have been identified from these urine specimens (Table 1).

The most frequently isolated microorganism in UTI agent samples was Escherichia coli (68.01\%); followed by Klebsiella, Enterobacter, Pseudomonas, and Proteus species. Particularly in recent years, the incidence of high resistant gram-negative bacteria in complicated urinary tract infections has increased. In accordance with our study, the most common UTI agents isolated from children in previous years were reported as Esc- herichia coli, followed by Klebsiella, Proteus species, Enterococcus faecalis and Pseudomonas species [11][14] E. coli is known as the most common bacteria (80\%) in children with UTI [14]. Klebsiella spp., Proteus spp., Enterobacter spp., Serratia spp., Pseudomonas spp. and Proteus mirabilis are among the other most common infection agents [15].

\section{UTI Risk Factors}

The incidence of UTI varies according to age and gender. In childhood, UTI is one of the most common infectious diseases, especially in children under two years. The incidence of UTI in girls increases after the first age and the onset of toilet training. According to national and international studies, the majority of children with UTI are girls. The distribution of UTI agents according to age groups and gender status is presented in Table 2. Regarding age groups of patients, 428 (59.5\%) patients are in 0-2 age, 153 (21.3\%) in 2-6, 116 (16.1\%) in 6-12, $22(3.1 \%)$ in 12-17 age. In a similar study, 1021 (23.1\%) patients were under one year of age, 1547 (34.9\%) were 1-5, 1018 (22.9\%) were 6-10, and 835 (19.1\%) were over 10 years old [16]. Moreover, another similar study found that $0-2$ age group patients constitute a percentage of $56.6 \%(n=125)$, followed by $3-7(26.2 \%, n=58)$ and 8-15 age groups $(17.2 \%, n=38)$ [17]. Therefore, UTI is observed more often in 0-2 age group compared to other age groups as supported by this study and several other studies.

Table 1. Descriptive information about the bacterial strains isolated from UTI agent samples in this study.

\begin{tabular}{|c|c|c|}
\hline Infection agents & Number & Percentage (\%) \\
\hline Escherichia coli & 489 & 68.01 \\
\hline Klebsiella pneumoniae & 142 & 19.75 \\
\hline Klebsiella oxytoca & 24 & 3.34 \\
\hline Enterobacter cloacae & 16 & 2.23 \\
\hline Pseudomonas aeruginosa & 14 & 1.95 \\
\hline Proteus vulgaris & 7 & 0.97 \\
\hline Providencia rettgeri & 7 & 0.97 \\
\hline Enterobacter aerogenes & 5 & 0.70 \\
\hline Proteus mirabilis & 5 & 0.70 \\
\hline Morganella morganii & 3 & 0.42 \\
\hline Citrobacter freundii & 2 & 0.28 \\
\hline Cedecea lapagei & 1 & 0.14 \\
\hline Citrobacter koseri & 1 & 0.14 \\
\hline Citrobacter werkmanii & 1 & 0.14 \\
\hline Serratia fonticola & 1 & 0.14 \\
\hline Serratia marcescens & 1 & 0.14 \\
\hline
\end{tabular}


Table 2. Distribution of UTI agents according to age and gender groups in children.

\begin{tabular}{|c|c|c|c|c|c|c|}
\hline & \multicolumn{4}{|c|}{ Age (years) } & \multicolumn{2}{|c|}{ Gender } \\
\hline & $0-2$ & $2-6$ & $6-12$ & $12-17$ & Female & Male \\
\hline E. coli & 259 & 120 & 98 & 12 & 408 & 81 \\
\hline Klebsiella spp. & 130 & 13 & 16 & 7 & 104 & 62 \\
\hline $\begin{array}{c}\text { Enterobacter } \\
\text { spp. }\end{array}$ & 18 & 2 & 0 & 1 & 9 & 12 \\
\hline P. aeruginosa & 7 & 4 & 2 & 1 & 9 & 5 \\
\hline Proteus spp. & 5 & 7 & 0 & 0 & 9 & 3 \\
\hline M. morganii & 3 & 0 & 0 & 0 & 1 & 2 \\
\hline Citrobacter spp. & 2 & 1 & 0 & 1 & 3 & 1 \\
\hline P. rettgeri & 2 & 5 & 0 & 0 & 6 & 1 \\
\hline Serratia spp. & 2 & 0 & 0 & 0 & 1 & 1 \\
\hline C. lapagei & 0 & 1 & 0 & 0 & 1 & 0 \\
\hline Total cases & 428 & 153 & 116 & 22 & 551 & 168 \\
\hline
\end{tabular}

In accordance with other studies in the literature, this study found that $76.6 \%$ of the patients were girls, whereas only $23.4 \%$ were boys. In similar studies, $61.5 \%$ and $51 \%$ of patients were girls in 0-17 and 0-15 age groups, respectively $[16,17]$. Thus, the ratio of girls with UTI was found to be higher than that of boys. Similarly, $77.7 \%$ of patients $(n=525)$ were girls and $59.1 \%(n=399)$ were under the age of two [18]. Therefore, the findings of this study are consistent with previous studies regarding both age and gender groups in children.

In our study, the most common observed agent was $E$. coli (56.8\%) across all age groups. However, the reproductive frequency in $E$. coli decreased as the age advanced in children. The situation was similar for not only in Klebsiella, but Enterobacter sp. and P. aeroginosa. However, contrary to our study, Topal (2018) found that the reproductive frequency in $E$. coli increased as the age advanced [17].

\section{Antizbiotic resistance}

UTI in childhood causes important problems that affect their life standard. Therefore, quick and approp- riate diagnosis and suitable empirical therapy are crucial for children with UTI. The antimicrobial resistance of causative agents varies depending on many factors. In any empirical therapy, the causative agents and the lowest antimicrobial resistance for this microorganism should be considered. Low-spectrum antibiotics should be used as a priority in the treatment of UTI due to the reliability, cost-effectiveness, and development of antibiotic resistance. In children with a risk of increased antibiotic resistance, broad-spectrum antibiotics are used. Although amoxicillin, amoxicillin-clavulanate, cephalosporins, nitrofurantoin, and TMP-SMX are the most frequently prescribed drugs in the UTI treatment in Turkey, ampicillin and TMP-SMX are frequently used in empirical therapies [17].

In this study, among 19 different antimicrobial agents, the highest resistance rates were against ampicillin, amoxicillin/clavulanate, cephalosporin group, TMP/SMX, and aztreonam, respectively. The lowest resistance rates were observed against imipenem, amikacin, and meropenem, respectively (Figure 1). Resistance against these antibiotics was found to be mainly in E. coli and 
Klebsiella strains (Table 3). Low resistance against amikacin and imipenem antibiotics was also reported and amikacin resistance was found to be quite low in $E$. coli and Klebsiella strains, in accordance with our study [17]. Aminoglycoside group antibiotics are one of the preferable antibiotics owing to low resistance in the treatment of UTI as supported by the findings of literature. Moreover, imipenem is noted as a broad-spectrum antibiotic that is less frequently used and it can be preferred in cases with resistance against other antibiotics.

Our study indicated that ampicillin (62.1\%), amoxicillinclavulanate (45.5\%), and TMX/SMX (37.4\%) resistance were quite high in $E$. coli strains. Also, there was a resistance development for TMP/SMX (37.1\%) and therefore, this antibiotic could not be used in the first stage treatment. Similarly, it is also reported that resistance values against ampicillin and TMP-SMX were high [19]. In Turkey, resistance values of E. coli against TMP-SMX and ceftriaxone were reported to be $34.7 \%, 17 \%$, respectively [20]. In another study, resistance rates of ampicillin and TMP-SMX in E. coli were $81.5 \%$ and $67 \%$, respectively [21]. Kömürlüoğlu et al. (2017) reported that ampicillin and TMP-SMX resistance values were found to be $68.9 \%$ and $46.7 \%$ in E. coli, whereas the values were $100 \%$ and $38.6 \%$ in Klebsiella spp., respectively. Moreover, in a previous study in Turkey, ampicillin resistance values were $56.4 \%, 78.3 \%$, and $42.3 \%$ in E. coli, Klebsiella species and Proteus species, respectively [21]. Consequently, a high rate of ampicillin resistance detected in our study was consistent with findings of previous literature.
The resistances against ampicillin (96.9\%) and nitrofurantoin (76.4\%) were also found to be relatively high in Klebsiella species which is the second most common agent isolated in this study (Table 3). A possible reason behind these high values is that these agents are frequently used in the empirical treatment of UTI in Turkey. However, dissimilar to other agents, the resistance against nitrofurantoin in Klebsiella species was quite noteworthy in our study. In addition, aztreonam resistance values were found to be $27.8 \%$ and $44.2 \%$ in E. coli and Klebsiella species, respectively.

There is also a high degree of resistance against cephalosporins, which are frequently used in the treatment of UTI. Our study found that there were resistances against cefixime, ceftriaxone and ceftazidime antibiotics which are among the $3^{\text {rd }}$ generation cephalosporins, whereas there was resistance development against cefepime that is among the $4^{\text {th }}$ generation cephalosporins (Table 3). The development of resistance against cefixime (38.2\%), ceftriaxone (34.2\%), ceftazidime (32.3\%), and cefepime (29.6\%) antibiotics over time can also be associated with the frequent use of these antibiotics. A previous study reported that resistance values of $E$. coli and Klebsiella spp. against cefixime, a common oral antibiotic, were $31.3 \%$ and $38.2 \%$, respectively. The highest levels of cefepime resistance were in Acinetobacter (53.3\%), Klebsiella spp. (36.9\%), and E. coli (26.8\%). Ceftazidime resistance values were $30.2 \%$ in E. coli, $39.4 \%$ in Klebsiella spp., $15.1 \%$ in Pseudomonas, $40.5 \%$ in Enterobacter, and $47.8 \%$ in Acinetobacter. The highest rates of ceftriaxone resistance were found in Enterobacter (47.1\%), Klebsiella spp. (41.6\%) and E. coli (31.5\%) [14]. In

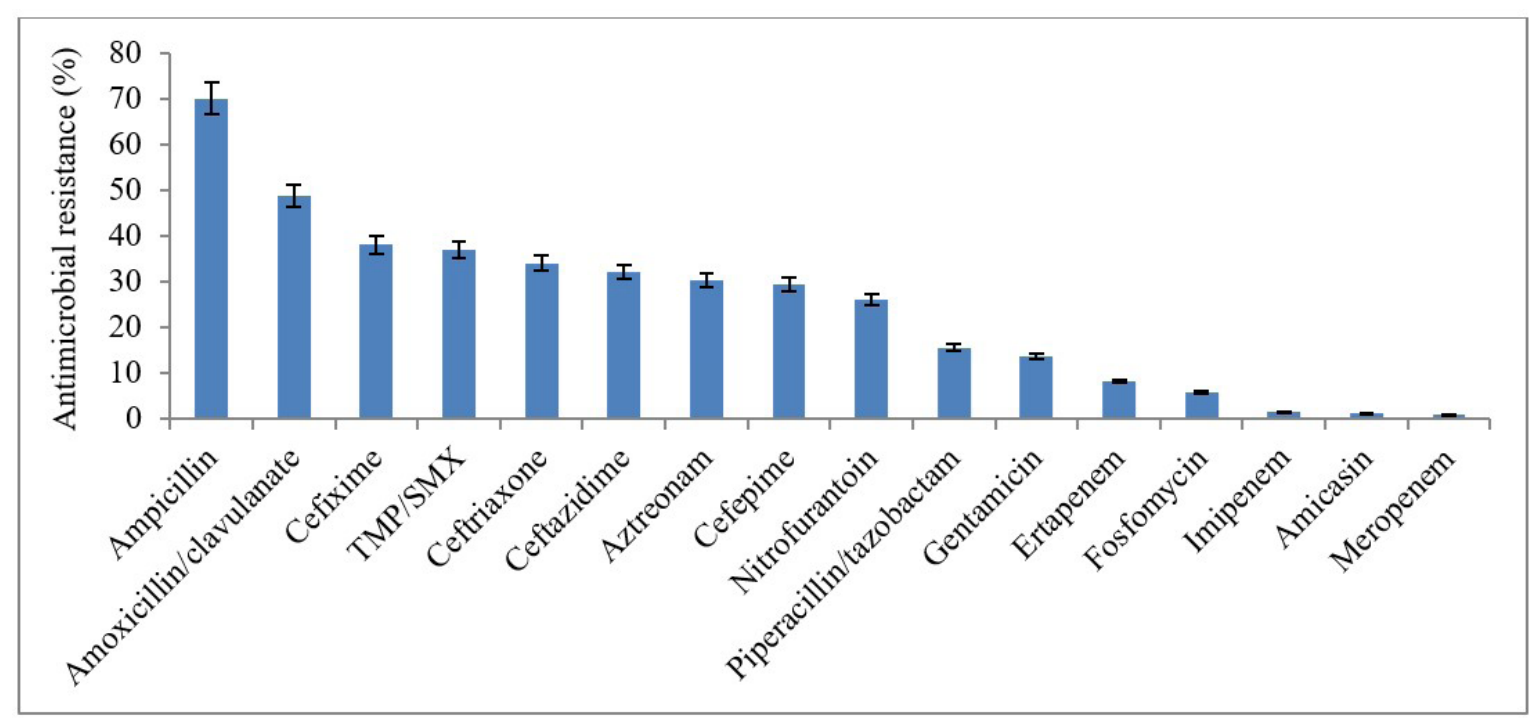

Figure 1. Antimicrobial resistance distribution of urinary tract infection agents isolated from children. 
270 N. Iilil et al. / Hacettepe J. Biol. \& Chem., 2020, 48 (3), 265-274

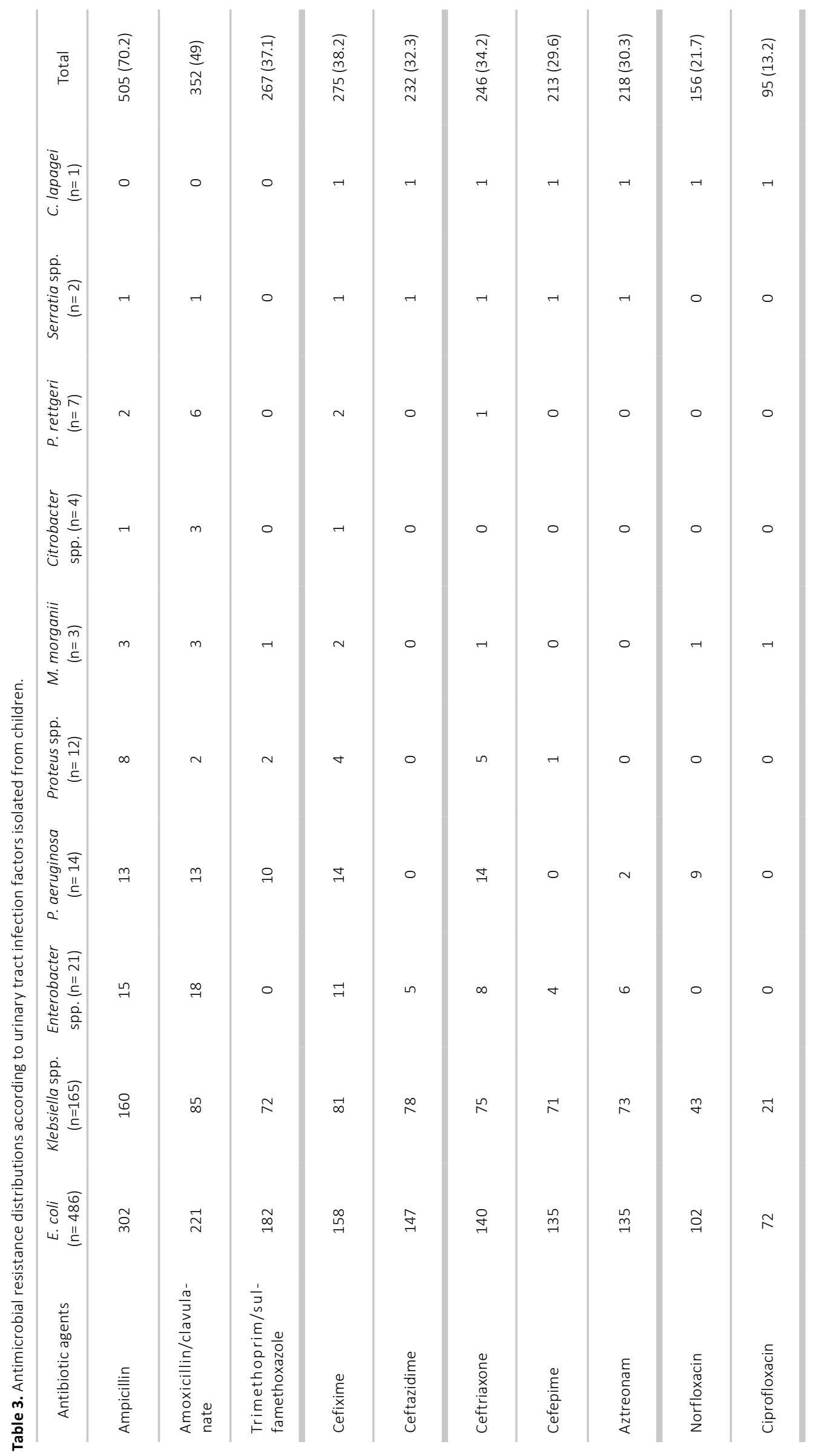


N. Idil et al. / Hacettepe J. Biol. \& Chem., 2020, 48 (3), 265-274 271

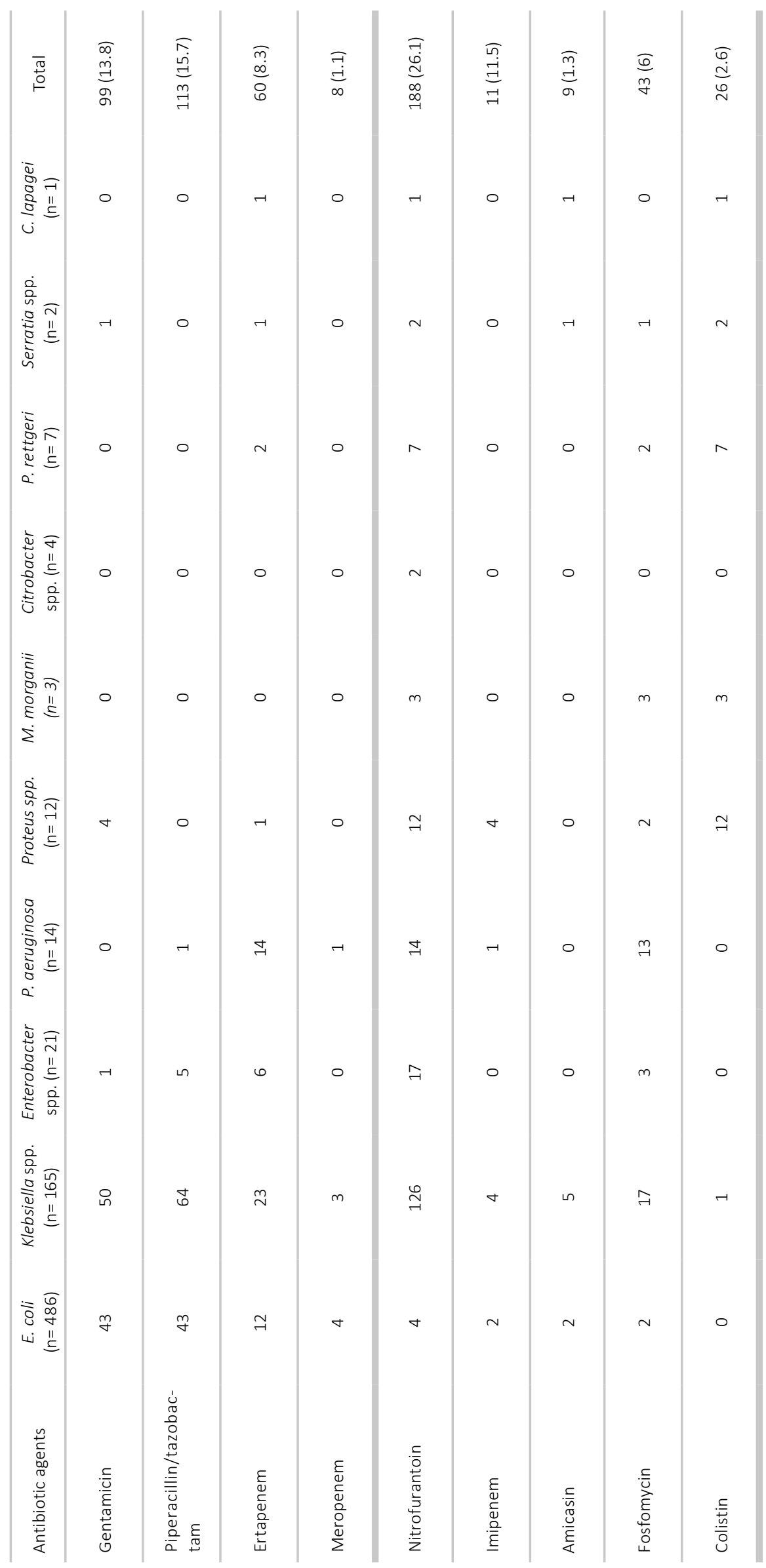


a study in Greece, the sensitivity to the $3^{\text {rd }}$ generation cephalosporins (cefotaxime, ceftriaxone, and ceftazidime) in E. coli was found to be between $95.6 \%$ and $97.4 \%$. In our study, the cephalosporin resistance was found to be slightly higher compared with the literature. It is thought that the expansion in the usage area of cephalosporin group antibiotics which are used as the first choice and the use of prophylactic antibiotics play an important role in the development of resistance against these antibiotics. Given the presence of increasing resistance, especially the $3^{\text {rd }}$ generation cephalosporins should be used more selectively.

Carbapenems are the most preferred group for parenteral treatment of UTI caused by microorganisms which are resistant to many antibiotics. It was reported that carbapenem resistance was the highest in E. coli strains (18.5\%) [21], whereas the carbapenem resistance was reported as $1.2 \%$ in a different study [22]. In the studyof Konca et al. [23], imipenem and ertapenem resistance values were found to be $4.1 \%$ and $4.6 \%$ in all gram-negative bacteria, respectively. In another study, meropenem resistance was $1.3 \%$, imipenem resistance was $1.5 \%$, and ertapenem resistance was $1.7 \%$ in $E$. coli [19]. In our study, the low rate of resistance against carbapenem group antibiotics was identified in E. coli and Klebsiella species. Carbapenem resistance was found to be quite low in accordance with other studies in the literature and there has been no significant increase in the resistance compared to previous studies.

In 0-2 age group, there were high levels of resistance against all of the tested antibiotics in this study (Figure 2). The highest resistance was against gentamicin (78.8\%), whereas the lowest resistance was against imipenem (45.5\%). Among the age groups, the lowest antibiotic resistance levels were found in 12-17 age group. In this group, the highest resistance was against meropenem (12.5\%), whereas the lowest resistance was against ertapenem (1.7\%). Antibiotic resistance values in the four different age groups $(0-2,2-6,6-12$, and 12-17) indicated a normal distribution except for 12-17 age group ( $p=0.44)$ but it was also evaluated as in a normal distribution. According to statistical analysis results, antibiotic resistance was significantly higher in 0-2 age group (Group 1), whereas in 12-17 age group (Group 4), the resistance was significantly lower than other age groups $(p<0.05)$ (Table 4$)$. UTI agents and antibiotic resistance were evaluated in children under two years old in a joint study comprising 18 pediatric nephrology centers from 10 European countries [24] Springer-Verlag Berlin Heidelberg. Knowledge of the distribution spectrum of causative organisms and their resistance patterns has become a core requirement for the rational and effective management of urinary tract infections. In the context of a prospective trial on the use of antibiotic prophylaxis in infants with underling kidney malformations, we conducted an online survey among paediatric nephrologists on positive urine cultures (July 2010-June 2012, which predominantly isolated E. coli strains and found that the highest antibiotic resistance values were against ampicillin, trimethoprim, cephalosporins and co-amoxiclav derivative antibiotics, in accordance with our study. Therefore, these resistance levels create a severe threat particularly for children not only in Turkey but also in the world.

In conclusion, ampicillin, cephalosporins, amoxicillinclavulanate, and TMP/SMX should not be empirically commenced. In order to avert a rapid resistance development that is closely associated with widespread and inappropriate antibiotic use, the use of random antibiotics should be avoided and particularly the $3^{\text {rd }}$ generation cephalosporins should be used more selectively. Although our data reflect only the results of patients admitted to a single hospital, classification of pathogens and determination of resistance rates against oral and parenteral antibiotics make our study valuable as it assesses the resistance patterns in patients.

\section{References}

1. R. Quigley, Diagnosis of urinary tract infections in children, Curr. Opin. Pediatr., 21 (2009) 194-198.

2. İ. Şahin, Ş. Öksüz, D. Kaya, I. Şencan, A. Gülcan, Antibiotic susceptibility of uropathogenic gram negative rods isolated from inpatient and outpatient children, ANKEM Derg. 18 (2004) 101-104.

3. B. Becknell, M. Schober, L. Korbel, J.D. Spencer, The diagnosis, evaluation and treatment of acute and recurrent pediatric urinary tract infections, Expert Rev. Anti. Infect. Ther., 13 (2015) 81-90.

4. S. Swerkersson, U. Jodal, C. Åhrén, S. Hansson, Urinary tract infection in small outpatient children: The influence of age and gender on resistance to oral antimicrobials, Eur. J. Pediatr., 173 (2014) 1075-1081.

5. P. H.Conway, A.Cnaan, T. Zaoutis, B. V. Henry, R. W. Grundmeier, R. Keren, Recurrent urinary tract infections in children: Risk factors and association with prophylactic antimicrobials, J. Am. Med. Assoc., 298 (2007) 179-186.

6. N. Taneja, S. S. Chatterjee, M. Singh, S. Singh, M. Sharma, Pediatric urinary tract infections in a tertiary care center from north India, Indian J. Med. Res. 131 (2010) 101-105. 


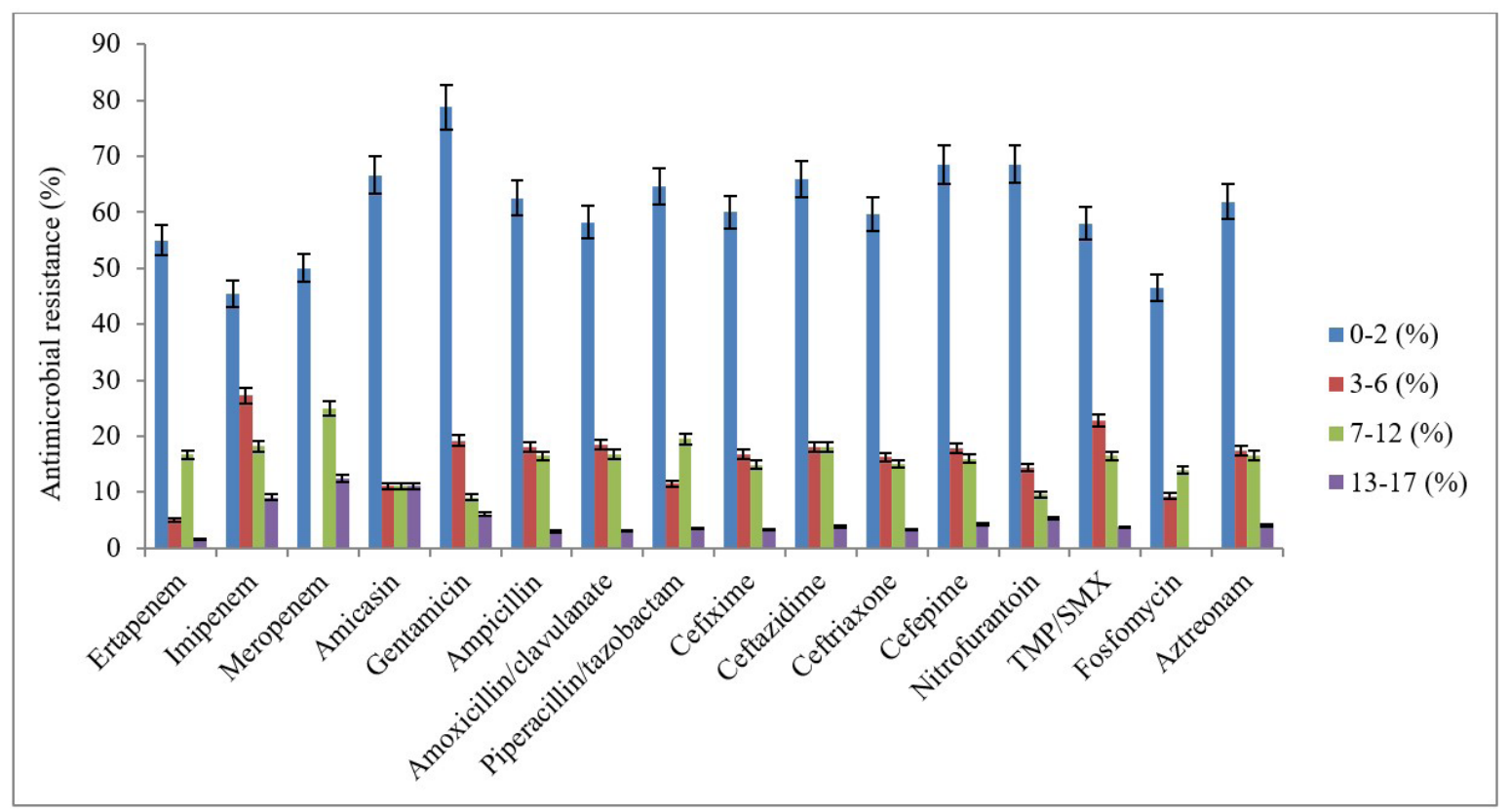

Figure 2. Comparison of antimicrobial resistance of urinary tract infection agents isolated from children with age groups.

Table 4. Statistical analysis of antibiotic resistance levels in four different age groups (Group 1: 0-2, Group 2: 2-6, Group 3: 6-12, and Group 4: 12-17).

\begin{tabular}{|c|c|c|c|c|c|c|}
\hline \multirow{2}{*}{\multicolumn{2}{|c|}{ (I) VAR00001 }} & \multirow{2}{*}{$\begin{array}{l}\text { Mean Differen- } \\
\text { ce (I-J) }\end{array}$} & \multirow{2}{*}{ Std. Error } & \multirow{2}{*}{ Significance } & \multicolumn{2}{|c|}{ 95\% Confidence Interval } \\
\hline & & & & & Lower Bound & $\begin{array}{l}\text { Upper } \\
\text { Bound }\end{array}$ \\
\hline \multirow{3}{*}{1.00} & 2.00 & $70.52632 *$ & 19.90999 & .011 & 12.7880 & 128.2646 \\
\hline & 3.00 & $73.31579 *$ & 19.75320 & .008 & 15.8618 & 130.7698 \\
\hline & 4.00 & $93.84211^{*}$ & 19.10285 & .001 & 37.4724 & 150.2118 \\
\hline \multirow{3}{*}{2.00} & 1.00 & $-70.52632 *$ & 19.90999 & .011 & -128.2646 & -12.7880 \\
\hline & 3.00 & 2.78947 & 7.67403 & 1.000 & -18.5854 & 24.1644 \\
\hline & 4.00 & $23.31579 *$ & 5.79835 & .004 & 6.3200 & 40.3116 \\
\hline \multirow{3}{*}{3.00} & 1.00 & $-73.31579 *$ & 19.75320 & .008 & -130.7698 & -15.8618 \\
\hline & 2.00 & -2.78947 & 7.67403 & 1.000 & -24.1644 & 18.5854 \\
\hline & 4.00 & $20.52632^{*}$ & 5.23472 & .005 & 5.2072 & 35.8454 \\
\hline \multirow{3}{*}{4.00} & 1.00 & $-93.84211^{*}$ & 19.10285 & .001 & -150.2118 & -37.4724 \\
\hline & 2.00 & $-23.31579^{*}$ & 5.79835 & .004 & -40.3116 & -6.3200 \\
\hline & 3.00 & $-20.52632 *$ & 5.23472 & .005 & -35.8454 & -5.2072 \\
\hline
\end{tabular}


7. S. Habib, Highlights for management of a child with a urinary tract infection. Int. J. Pediatr., (2012).

8. N. Shaikh, N. E. Morone, J. E. Bost, M. H. Farrell, Prevalence of urinary tract infection in childhood: A meta-analysis, Pediatr. Infect. Dis. J., 27 (2008) 302-308.

9. M. Wennerström, S. Hansson, U. Jodal, E. Stokland, Primary and acquired renal scarring in boys and girls with urinary tract infection, J. Pediatr., 136 (2000) 30-34.

10. S. Hellerstein, J. S.Linebarger, Voiding dysfunction in pediatric patients, Clin. Pediatr. (Phila)., 42 (2003) 43-49.

11. A. M. Sefton, The impact of resistance on the management of urinary tract infections. Int. J. Antimicrob. Agents., 16 (2000) 489-491.

12. J.S. Stultz, C.D. Doern, E. Godbout, Antibiotic resistance in pediatric urinary tract infections. Curr. Infect. Dis. Rep., 18 (2016) 1-9.

13. Urinary tract infection: Clinical practice guideline for the diagnosis and management of the initial UTI in febrile infants and children 2 to 24 months- Amer. Acad. Pediat., 128 (2011) 595-610.

14. R.J. Gaspari, E. Dickson, J. Karlowsky, G. Doern, Antibiotic resistance trends in paediatric uropathogens, Int. J. Antimicrob. Agents, 26 (2005) 267-271.

15. F.A. Orrett, P.J. Brooks, E.G Richardson, S. Mohammed, Paediatric nosocomial urinary tract infection at a regional hospital, Int. Urol. Nephrol.,31 (1999) 173-179.

16. A. Kömürlüoğlu, K. Aykaç, Y. Özsürekçi, S. Tanir Başaranoğlu, A. Biçakçigil, Ü. Liste, B. Altun, B. Sancak, A. B. Cengiz, A. Kara, M. Ceyhan, Antibiotic resistance distribution of gramnegative urinary tract infectious agents: single center experience, Turkish J. Pediatr. Dis. (2017) 10-17.

17. Y. Topal, Çocuklarda idrar yolu enfeksiyonu: güncel veriler eşliğinde bir değerlendirme, Ortadoğu Tıp Derg., 10 (2018) 26-33.

18. R.H. Hanna-Wakim, S.T. Ghanem, M.W. El Helou, S.A. Khafaja, R.A. Shaker et al., Epidemiology and characteristics of urinary tract infections in children and adolescents, Front. Cell. Infect. Microbiol., 26 (2015) 5-45.

19. H.F. Shao, W.P. Wang, X.W. Zhang, Z.D. Li., Distribution and resistance trends of pathogens from urinary tract infections and impact on management, ZhonghuaNan Ke Xue 9 (2003) 690-696.

20. B. Çoban, N. Ülkü, H. Kaplan, B. Topal, H. Erdoğan, E. Baskin, Çocuklarda idrar yolu enfeksiyonu etkenleri ve antibiyotik dirençlerinin beş yillik değerlendirmesi, Turk Pediatr. Ars.49 (2014) 124-129.

21. R. Yılmaz, E. Karaaslan, M. Özçetin, B. Arslan, M. Kilinç, N. Ö. K. Çocuklarda idrar yolları enfeksiyonu etkenleri ve antibiyotik duyarlılıkları Agents of urinary tract infections in children and their antibiotic susceptibility, J. Contempor. Med., 2 (2012) 17-21.

22. C. Konca, M. Tekin, F. Uckardes, S. Akgun, H. Almis, I. H. Bucak, Y. Genc, M.Turgut, Antibacterial resistance patterns of pediatric community-acquired urinary infection: Overview. Pediatr. Int., 59 (2017) 309-315.

23. E. Mantadakis, E.K. Vouloumanou, M. Panopoulou, E. Tsouvala, A. Tsalkidis, A. Chatzimichael, M. E. Falagas, Susceptibility patterns of uropathogens identified in hospitalised children with community-acquired urinary tract infections in Thrace, Greece. J. Glob. Antimicrob. Resist., 3 (2015) 85-90.

24. I. Alberici, A. K. Bayazit, D. Drozdz, S. Emre, M. Fischbach, J. Harambat, A. Jankauskiene et al., Pathogens causing urinary tract infections in infants: a European overview by the ESCAPE study group, Eur. J. Pediatr., 174 (2015)783-90. 